\title{
Governmental Engineering in the Iraqi e-Government
}

\author{
Mohammed Kamal Ahmed ${ }^{1}$, Dr. Amer Saleem Elameer ${ }^{2}$, Eng. Ali Hussein Mousa ${ }^{3}$ \\ Informatics Institute for Postgraduate Studies ${ }^{1}$ \\ University of information technology and communication ${ }^{2}$ \\ Ministry of Higher Education and Scientific Research, Baghdad - Iraq ${ }^{3}$
}

\begin{abstract}
Electronic Government is considered an effective tool for the organizations. New technologies of electronic communications through the use of the web provided the basis for the of Electronic Government. This research provides a theoretical framework of the concepts and dimensions of Electronic Government. This is done through the emphasis on the role of strategical approach achieving efficient and effective performance of organizations, within this new filed ,to accomplish various managing transactions The research provides many results were load to make the following recommendations :-

1-It is necessary for all the countries to faces on supplying and the Electronic Government order to raise the informational conscious for the workers.

2- Invest the capabilities of information technology in activation the Electronic Government. The aim of this project is to It provides new evidence and new analysis to reflect on the potential of e-government to support the government engineering by using information and communications technology.
\end{abstract}

Keywords: e-Government, ICT, G2C, G2B, e-CRM

\section{INTRODUCTION}

Electronic governance or e-governance is the application these authors, e-governance is a broader concept and of information and communication technology (ICT) for includes the use of ICT by government and civil society to delivering government services, exchange of information, promote greater participation of citizens in the governance communication transactions, integration of various stand- of political institutions, e.g., use of the Internet by alone systems and services between government-to- politicians and political parties to elicit views from their customer (G2C), government-to-business (G2B), constituencies in an efficient manner, or the publicizing of government-to-government $(\mathrm{G} 2 \mathrm{G})$ as well as back office views by civil society organizations which are in conflict processes and interactions within the entire government with the ruling powers (Howard, 2001 and Bannister and framework. Through e-governance, government services Walsh, 2002). It is clear that considerable confusion exists will be made available to citizens in a convenient, efficient in explaining e-government and e-governance. In what and transparent manner. The three main target groups that follows, we attempt to resolve the ambiguities and come can be distinguished in governance concepts are up with clear and nonoverlapping definitions. Our premise government, citizens and businesses/interest groups. In e- is simple: e-government's focus is on constituencies and governance there are no distinct boundaries. Generally four stakeholders outside the organization, whether it is the basic models are available - government-to-citizen government or public sector at the city, county, state, (customer), government-to-employees, government-to- national, or international levels. On the other hand, egovernment and government to business

\section{TAXANOMY OF E-GOVERNMENT SERVICES} governance focuses on administration and management within an organization, whether it is public or private, large or small .

According to Backus, "the three main target groups that Based on this classification, e-governance concerns can be distinguished in e-governance (we call it e- internally-focused utilization of information and internet Government) concepts are government, citizens and technologies to manage organizational resources - capital, businesses/interest groups. The external strategic human, material, machines and administers policies and objectives focus on citizens and businesses and interest procedures (both for the public sector or private sector). groups, the internal objectives focus on government itself" The telecommunications network that facilitates e(Backus, 2001). In the following discussion, we include governance is the Intranet. What has been generally termed another one - Government to Constituencies. as G2E (Government to Employee) will be now under the label of e-governance. E-governance deals with the online

\section{E-GOVERNANCE AND E-GOVERNMENT}

Some authors contend that e-government constitutes only subset (though a major one) of e-governance. According to to important applications, and content and collaboration 
with other government employees anytime, anywhere. Any use of multi-media broadcasting, radio networks, computer interaction of a governmental agency $(G)$ with outside networks, mobile phone communication technologies, and constituencies is called e-government. Outside other similar electronic devices. Internal information constituencies can be citizens (C), businesses (B), or other systems of Government agencies, information kiosks, governmental agencies (G) themselves. Government automated telephone information services, SMS services agencies should be held responsible and accountable for and other systems all comprise E-Government services. All their actions in collecting taxes from its citizens in various these are applications of Information and Communications forms and then using these revenues to provide diverse Technologies (ICT) to improve the services of the services to its constituents in the areas of defense, security, Government towards its primary clients: the citizens A economic vitality, education, and health care. To perform brief history of E-Government indicates that, in the 1990s, all these activities efficiently and effectively, if the some governments around the world adopted e-government governmental agencies deploy information \& Internet solutions, but the scope and pace of adoption varied technologies, it is called e-government. The TC network significantly, ranging from simple web presence and onethat provides these is the Extranet or the Internet itself. way communication to two-way communication and One special type of $\mathrm{G} 2 \mathrm{C}$ is when elected representatives transactions with citizens and business. Finally, this moved and political parties interact with the citizens nationally or on to more integrated web presence and edemocracy. At a in their constituencies. This type of G2C is also called e- local level, many agency started to develop E-Government democracy. Different categories of e-government services strategies between 1994 and 1999 and many local are described in the next section. In case of private governments around the world already have an official web enterprises, any interaction through information systems site. These web sites offer a variety of services, ranging with external organizational entities - customers, suppliers, from online payments, licensing and permit applications to partners in the global supply chain management fall within simple provision of online documentation and email the domain of inter-organizational systems. Such systems communication; the scope has continued to expand more generally utilize extranets. Under this category, we will advance to e-participants have B2B (e-procurement, e-CRM, e-Market Place, eLearning), B2C (e-tailing, e-banking, e-insurance, eGrocery, e-ticketing), and even $\mathrm{C} 2 \mathrm{C}$ - primary examples being Craig's list and e-Bay.

According to Sheridan and Riley (2006), e-governance is a broader concept that deals with the whole spectrum of the relationship and networks within government regarding the usage and application of ICTs whereas e-government is limited to the development of online services). According to them, e- government is an institutional approach to jurisdictional political operations where as e-governance is a procedural approach to co-operative administrative relations, i.e. the encompassing of basic and standard procedures within the confines of public administration.

Some researchers formulated a four-phase e-governance (we call it eGovernment) model. According to this model, governments start with the delivery of online information, but soon public demand and internal efficiency ask for more complex services. In each of the four phases, the delivery of online services and use of ICTs in government operations serve one or more of the aspects of egovernance: democracy, government, business.

\section{E-GOVERNMENT IN IRAQ}

The internet is now ubiquitous. In the past, it was mainly used for educational and information provision and sharing purposes, but internet applications now facilitate many essential day-to-day activities. E-Government is an important application of the internet and is used by authorities to encourage broad use of computers and to facilitate communication and interactions with its institutions, citizens and businesses . E-Government is the use of electronic media in the facilitateon of government processes. It covers a wide range of applications making

\section{E-GOVERNMENT REQUIREMENTS}

Implementation of E-Government idea requires lots of efforts in a systematic and designed plan. These requirements can be summarized below:

1. Plan or Strategies are essential to e-government formulation because they provide objectives for state agencies and governments.

2. Hardware, Using communication networks as correspondence highway between main government structure and lower levels of government agencies and customers of governmental services

3. Software, use in homes, schools, workplace, economy, government, everyday life, number of internet users, cellular users.

4. Human Recourses, ICT education, training, development programs, available skilled workforce, mass education, employment and skills.

\section{CONCLUSION \& SUGGESTIONS FOR FUTURE WORKS}

In the modern world there is an increase in dependence of information and knowledge management to gain competitive advantage in the social and economic arenas. Governments in developed countries have invested in ICT to ensure that their strategies succeed through implementation and use of ICT to run their operations (Egovernance). Iraq government are only in the initial phases of adopting ICT to improve financial management information and reporting, streamline the delivery of government services, enhance communication with the citizenry, and serve as a catalyst for empowering citizens to interact with the government At present the government should ensure that every user has ICT units for training and 
supporting ICT activities. The analysis highlights the Pew Internet and American Life Project is employed for actions that would be helpful at multiple levels and required 3 years to implement these strategies: statistical examination. The paper unfolds in eight parts, including the foregoing introduction. The next section First :- Year, For Leaders and Political decision makers. addresses the contextual background of egovernment use. Second :- Year, For Education (Lecturers and Students). Third :- Year, For Employees.

\section{THEORETICAL BACKGROUND FOR E- GOVERNMENT}

Then determinants of e-government use are derived from an expanse of relevant literature. After the description of data, measurements, and empirical strategy, the results of the multivariate regression analysis are presented. The following two sections discuss further implications for The common definition of e-government refers to the use practitioners and researchers, respectively. The final by government of information and communication section offers some concluding remarks.

technologies (ICTs) to deliver information and services to citizens, businesses, and public agencies (Carter \& Belanger, 2005; Edmiston, 2003; Sipior \& Ward, 2005; West, 2004). For the delivery of information and services, public administration, with technological advances, has been experiencing a change from the bureaucratic, inwardlooking approach to a citizencentric, outward-looking approach that prioritizes the concerns and needs of users or customers (Ho, 2002; Thompson, Rust, \& Rhoda, 2005). As Layne and Lee (2001) mentioned, government processes are being organized for citizens' convenience rather than the convenience of government agencies. More recently, according to International City/ County Management Association (2011), e-government-driven changes identified by local government managers are the improvements in city/county governments' communication with the public and customer services more than such managerial impacts as re-engineering business processes, increasing efficiency, and reducing administrative costs.

Nevertheless, there is a relative paucity of systematic research that investigates citizens' use of e-government (Gauld, Goldfinch, \& Horsburgh, 2010; Helbig, GilGarcia, \& Ferro, 2009; Reddick, 2005; Streib \& Navarro, 2006). For a government to move toward a citizencentric, outwardlooking approach, understanding citizens' use of egovernment and identifying determinants of e-government use has a central importance for both researchers and practitioners. There is a concern beyond e-inclusion. With an increasing availability for a variety of e-government functions (e-service, e-information, and e-participation), the emerging concern about e-government becomes a question of why certain populations use those specific functions of e-government while others do not. In this regard, a research focus needs to address not only the existing divide between users and nonusers, but the difference in the degree of using e-government with respect to the type of its functions and reasons for that difference. Hence a research inquiry should go beyond "whether or not to use e-government?" and instead consider "for what purpose does one use e-government?" and then "what determines the degree of e-government use for the specific purpose?" The study empirically investigates the impact of various determinants (i.e., perception-based psychological factors, civic mindedness, information channels, trust in government, and sociodemographic backgrounds) on multiple types of egovernment use. The U.S.-based survey data from the 